\title{
PENANGANAN PEMBIYAAN BERMASALAH PADA BANK SYARIAH
}

\section{Sitti Saleha Madjid}

UIN Syarif Hidayatullah Jakarta || sittisalehamadjid@gmail.com

\begin{abstract}
Abstrak
Tujuan daripada penulisan ini untuk memahami pembiyaan bermasalah pada perbankkan syariah, beserta bagaimana cara menanganinya. Metode penulisannya yaitu kualitatif literatur, dengan mengumpulkan referensi dari literatur serta undang -undang dan peraturan pemerintah mengenai perbankkan. Dari penelusuran yang diadakan ditemukan kesimpulan. Adanya pembiayaan bermasalah pada bank syariah akan berakibat pada berkurang atau menurunnya pendapatan bank. Dari sisi nasional dapat mengurangi kontribusi bank dalam melakukan fungsi intermediarinya sehingganya tidak dapat memberikan kontribusi pada pembangunan dan pertumbuhan ekonomi.

Penanggulangan pembiayaan bermasalah dapat dilakukan melalui penyelesaian oleh bank sendiri secara bertahap dengan pendekatan persuasif. Bila tahap pertama tersebut telah dilakukan, maka dapat digunakan langkah dan tahapan berikutnya antara lain penyelesaian melalui debt collector, penyelesaian melalui Kantor Lelang, penyelesaian melalui badan peradilan (al-qadha), penyelesaian melalui badan arbitrase (tahkim) dan Penyelesaian melalui Direktorat Jenderal Piutang dan Lelang Negara (DJPLN) untuk bank-bank BUMN.
\end{abstract}

Kata Kunci: Pembiayaan Bermasalahah, Bank Syariah 


\title{
J-HES
}

Jurnal Hukum Ekonomi Syariah

Volume 2, No. 1, Januari-Juni 2018 | p-ISSN: 2549-4872 | e-ISSN: 2654-4970

\begin{abstract}
The purpose of this writing is to understand the problematic financing of sharia banking, along with how to handle it. The writing method is qualitative literature, by collecting references from the literature and laws and government regulations regarding banking. From the searches were found conclusions. The existence of non-performing financing in Islamic banks will result in reduced or decreased bank income. From the national side, it can reduce the contribution of banks in carrying out their intermediary functions so that they cannot contribute to the development and economic growth.

Tackling problematic financing can be done through a gradual settlement by the bank itself with a persuasive approach. If the first stage has been carried out, then the next steps and steps can be used, among others, settlement through debt collector, settlement through the Auction Office, settlement through the judiciary (al-qadha), settlement through the arbitration body (tahkim) and Settlement through the Directorate General of Debt and State Auction (DJPLN) for state-owned banks.
\end{abstract}

Keywords: Problematic Financing, Islamic Bank

\section{PENDAHULUAN}

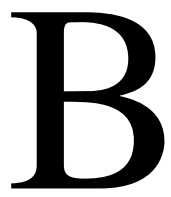

entuk penilaian tingkat kesehatan dari suatu bank antara lain dapat dilihat dari perkembangan aktiva produktif bermasalah dibandingkan dengan aktiva produktif yang dimilikinya. Secara kuantitatif perbandingan tersebut umumnya diwujudkan dalam bentuk rasio pembiayaan aktiva bermasalah atau sering diistilahkan dengan pembiayaan bermasalah (non performing financings-NPFs), yang di bank konvensional sering disebut dengan non-performing loan (NPL). Rasio pembiayaan bermasalah ini menjadi salah satu indikator penilaian terhadap perbankan syariah dalam mengelola penyaluran pembiayaannya. Menurut Bank Indonesia, suatu bank dikatakan sehat ketika rasio pembiayaan bermasalahnya berada di bawah 5 persen. Pada Desember 2015, secara kumulatif rasio pembiayaan bermasalah pada Bank Umum Syariah (BUS) dan Unit Usaha Syariah (UUS) tercatat sebesar 4,84 persen atau $\mathrm{Rp}$ 7,456 triliun dari total pembiayaan $\mathrm{Rp}$ 153,968 triliun. Dibandingkan dengan tahun sebelumnya NPF bank syariah mengalami penurunan tipis. Pada Desember 2014 NPF BUS dan UUS 
tercatat 4,95 persen, atau $\operatorname{Rp} 7,320$ triliun dari total pembiayaan $\mathrm{Rp}$ 147,944 triliun (Otoritas Jasa Keuangan, 2015,16), Sedangkan untuk BPRS, NPF tahun 2015 mengalami kenaikan dibanding 2014. Apabila pada tahun 2014, total NPF BPRS sebesar 7,89 persen dari total pembiayaan sebesar 5.004.909 juta, maka pada akhir 2015, NPFnya sebesar $8,20 \%$ dari total pembiayaan sebesar 5,765,171 juta. (Otoritas Jasa Keuangan, 2015,16)

Sebagaimana dimaklumi bahwa tujuan Bank memberikan pembiayaan antara lain untuk memperoleh imbalan atau pendapatan. Dari pendapatan yang diperoleh tersebut, akan dipakai oleh bank untuk keperluan pemberian imbalan kepada nasabah yang menempatkan dana pada bank, membayar biaya-biaya operasional bank, membentuk cadangan kerugian, dan memberikan dividen kepada pemegang saham bank. Dengan adanya kegagalan tersebut maka tujuan dari pembiayaan berupa kemanfaatan bagi bank dan nasabah penyimpan dana serta meningkatkan pertumbuhan ekonomi nasional akan mengalami disfungsi.

Oleh karena itu, dikaitkan dengan tujuan dan kemanfaatan dari adanya pemberian pembiayaan tersebut, adanya pembiayaan bermasalah akan menjadi persoalan besar ketika penanganan dan penyelesaiannya tidak dilaksanakan dengan sebaik-baiknya. Berkaitan dengan hal tersebut, dalam tulisan ini akan membahas persoalan persoalan penyelamatan dan penyelesaian pembiayaan bermasalah yang dapat dilakukan oleh bank-bank khususnya oleh bank-bank syariah.

\section{PEMBAHASAN}

\section{Pengertian Pembiayaan dan}

Pembiyaan Bermasalah

Berdasarkan Pasal 1 butir 25 UU

No.21 Tahun 2008 tentang Perbankan Syariah, yang dimaksud dengan Pembiayaan adalah penyediaan dana atau tagihan yang dipersamakan dengan itu berupa:

a. transaksi bagi hasil dalam bentuk Mudharabah dan Musyarakah;

b. transaksi sewa-menyewa dalam bentuk Ijarah atau sewa beli dalam bentuk Ijarah Muntahiyah bit Tamlik;

c. transaksi jual beli dalam bentuk piutang Murabahah, Salam, dan Istishna';

d. transaksi pinjam meminjam dalam bentuk piutang Qardh; dan 


\section{J-HES}

Jurnal Hukum Ekonomi Syariah

Volume 2, No. 1, Januari-Juni 2018 | p-ISSN: 2549-4872 | e-ISSN: 2654-4970

e. transaksi sewa-menyewa jasa dalam bentuk ijarah untuk transaksi multijasa.

Berdasarkan persetujuan atau kesepakatan antara Bank Syariah dan/atau UUS dan pihak lain yang mewajibkan pihak yang dibiayai dan/atau diberi fasilitas dana untuk mengembalikan dana tersebut setelah jangka waktu tertentu dengan imbalan ujrah, tanpa imbalan atau bagi hasil.

Dari ketentuan peraturan perundang-undangan di atas dapat disimpulkan bahwa setiap nasabah bank syariah yang mendapat pembiayaan dari bank syariah apapun jenisnya, setelah jangka waktu tertentu wajib untuk mengembalikan pembiayaan tersebut kepada bank syariah berikut imbalan atau bagi hasil atau tanpa imbalan untuk transaksi dalam bentuk qard.

Sedangkan yang dimaksud dengan "pembiayaan bermasalah" atau dalam bahasa Inggris disebut Non Performing Financings (NPFs), sama dengan Non Performing Loan (NPL) untuk fasilitas kredit, yang merupakan rasio pembiayaan bermasalah terhadap total pembiayaan, adalah pembiayaan yang kualitasnya berada dalam golongan kurang lancar, diragukan, dan macet. Dalam pengertian lain, pembiayaan bermasalah/ NPFs adalah Pembiayaan Non-Lancar mulai dari kurang lancar sampai dengan macet.

\section{Penetapan Kualitas Pembiayaan}

Berdasarkan ketentuan Bank Indonesia, kualitas pembiayaan dinilai berdasarkan aspek-aspek prospek usaha, kinerja (performance) nasabah, dan kemampuan membayar atau kemampuan menyerahkan barang pesanan. (Pasal 9 PBI No. 8/21/PBI/2006 dan PBI No. 10/24/PBI/2008). Atas dasar penilaian aspek-aspek tersebut, kualitas pembiayaan ditetapkan menjadi 5 (lima) golongan yaitu Lancar (current), Dalam Perhatian Khusus (under special mention), Kurang Lancar (substandard), Diragukan (doubtful), dan Macet (loss).

Dalam praktik perbankan kualitas pembiayaan untuk golongan lancar disebut golongan I (satu), untuk golongan dalam perhatian khusus disebut golongan II (dua), untuk golongan kurang lancar disebut golongan III (tiga), untuk golongan diragukan disebut golongan IV (empat) dan untuk golongan macet disebut golongan V (lima). 
Kriteria komponen dari aspek penetapan penggolongan kualitas pembiayaan untuk bank syariah ini diatur secara berbeda berdasarkan pengelompokan produk pembiayaan. (Lampiran I Surat Edaran Bank Indonesia No. 8/22/DPbS tanggal 18 Oktober 2006). Pengelompokan tersebut adalah sebagai berikut:

1) Penggolongan Kualitas Mudharabah dan Musyarakah;

2) 2)Penggolongan Kualitas Murabahah, Istishna, Qardh, dan Transaksi Multijasa;

3) Penggolongan Kualitas Ijarah atau Ijarah Muntahiyah bi Tamlik; dan

4) Penggolongan Kualitas Salam.

Komponen penilaian terhadap masing-masing aspek kualitas pembiayaan sesuai dengan masingmasing produk pembiayaan, diuraikan dalam komponen-komponen sebagai berikut:

a. Aspek prospek usaha meliputi komponen-komponen:

1) potensi pertumbuhan usaha;

2) kondisi pasar dan posisi nasabah dalam persaingan;

3) kualitas manajemen dan permasalahan tenaga kerja;

4) dukungan dari group atau afiliasi; serta

5) upaya yang dilakukan nasabah dalam rangka memelihara lingkungan hidup (bagi nasabah berskala besar yang memiliki dampak penting terhadap lingkungan hidup).

b. Aspek kinerja (performance) nasabah meliputi komponenkomponen sbb:

1) perolehan laba;

2) struktur permodalan;

3) arus kas; dan

4) sensitivitas terhadap risiko pasar.

c. Aspek kemampuan membayar/ kemampuan menyerahkan barang pesanan meliputi penilaian terhadap komponen-komponen sbb:

1) ketepatan pembayaran pokok dan marjin/bagi hasil/fee;

2) ketersediaan dan keakuratan informasi keuangan nasabah;

3) kelengkapan dokumentasi Pembiayaan; kepatuhan terhadap perjanjian Pembiayaan;

4) kesesuaian penggunaan dana; dan

5) kewajaran sumber pembayaran kewajiban

Selanjutnya untuk menetapkan golongan kualitas pembiayaan, pada masing-masing komponen ditetapkan kriteria/kriteria-kriteria tertentu untuk masing-masing kelompok produk pembiayaan (contoh dalam tabel). (Lihat Lampiran I SEBI No. 8/22/DPbS

tgl 18 Oktober 2006) Sebagai contoh untuk produk murabahah, dari aspek 


\section{J-HES}

Jurnal Hukum Ekonomi Syariah

Volume 2, No. 1, Januari-Juni 2018 | p-ISSN: 2549-4872 | e-ISSN: 2654-4970

kemampuan membayar angsuran teratur dan meragukan, dokumentasi nasabah maka pembiayaan digolongkan perjanjian piutang kurang lengkap dan kepada:

pengikatan agunan kuat, terjadi

a. Lancar

Apabila pembayaran angsuran tepat waktu, tidak ada tunggakan, sesuai dengan persyaratan akad, selalu menyampaikan laporan keuangan secara teratur dan akurat, serta dokumentasi perjanjian piutang lengkap dan pengikatan agunan kuat.

\section{b. Dalam Perhatian Khusus}

Apabila terdapat tunggakan pembayaran angsuran pokok dan atau margin sampai dengan 90 (sembilan puluh) hari, selalu menyampaikan laporan keuangan secara teratur dan akurat, dokumentasi perjanjian piutang lengkap dan pengikatan agunan kuat, serta pelanggaran terhadap persyaratan perjanjian piutang yang tidak prinsipil.

\section{c. Kurang Lancar}

Apabila terdapat tunggakan pembayaran angsuran pokok dan atau margin yang telah melewati 90 (sembilan puluh) hari sampai dengan 180 (seratus delapan puluh) hari, penyampaian laporan keuangan tidak pelanggaran terhadap persyaratan pokok perjanjian piutang, dan berupaya melakukan perpanjangan piutang untuk menyembunyikan keseulitan keuangan.

\section{d. Diragukan}

Apabila terdapat tunggakan pembayaran angsuran pokok dan atau margin yang telah melewati 180 (seratus delapan puluh) hari sampai dengan 270 (dua ratus tujuh puluh) hari. Nasabah tidak menyampaikan informasi keuangan atau tidak dapat dipercaya, dokumentasi perjanjian piutang tidak lengkap dan pengikatan agunan lemah serta terjadi pelanggaran yang prinsipil terhadap persyaratan pokok perjanjian piutang.

\section{e. Macet}

Apabila terdapat tunggakan pembayaran angsuran pokok dan atau margin yang telah melewati 270 (dua ratus tujuh puluh) hari, dan dokumentasi perjanjian piutang dan atau pengikatan agunan tidak ada. 
Tabel 1:

Contoh Kriteria Penilaian Kualitas Pembiayaan Dari Segi Kemampuan Bayar Berdasarkan Kelompok Produk Pembiayaan

\begin{tabular}{|c|c|c|c|c|c|}
\hline $\begin{array}{c}\text { Jenis } \\
\text { Pembiaya } \\
\text { an }\end{array}$ & Lancar & DPK & $\begin{array}{l}\text { Kurang } \\
\text { Lancar }\end{array}$ & Diragukan & Macet \\
\hline $\begin{array}{c}\text { Mudharab } \\
\text { ah\& } \\
\text { Musyaraka } \\
\text { h }\end{array}$ & $\begin{array}{c}\text { Pembayaran } \\
\text { angsuran } \\
\text { pokok } \\
\text { pembiayaan } \\
\text { tepat waktu; } \\
\text { dan atau RP } \\
\text { sama atau } \\
\text { lebih dari } 80 \\
\% \mathrm{PP}\end{array}$ & $\begin{array}{c}\text { Terdapat } \\
\text { tunggakan } \\
\text { angsuran } \\
\text { pokok } \\
\text { pembiayaan } \\
\text { sampai } \\
\text { dengan } 90 \\
\text { hari; dan atau } \\
\text { RP sama atau } \\
\text { lebih dari } \\
80 \% \text { PP }\end{array}$ & $\begin{array}{c}\text { Terdapat } \\
\text { tunggakan } \\
\text { angsuran } \\
\text { pokok } \\
\text { pembiayaan } \\
\text { yang telah } \\
\text { melampaui } 90 \\
\text { hari; dan atau } \\
\text { RP di atas } 30 \\
\% \text { PP s/d } 80 \% \\
\text { PP } \\
\text { (30\%PP<RP<8 } \\
0 \% \mathrm{PP})\end{array}$ & $\begin{array}{c}\text { Terdapat } \\
\text { tunggakan } \\
\text { angsuran } \\
\text { pokok } \\
\text { pembiayaan } \\
\text { yang telah } \\
\text { melampaui } \\
120 \text { hari s/d } \\
180 \text { hari; dan } \\
\text { atau RP<30 } \\
\% \text { PP s/d } 3 \\
\text { periode } \\
\text { pembayaran }\end{array}$ & $\begin{array}{c}\text { Terdapat } \\
\text { tunggakan } \\
\text { angsuran } \\
\text { pokok } \\
\text { pembiayaan } \\
\text { yang telah } \\
\text { melampaui } \\
180 \text { hari; dan } \\
\text { atau RP < } 30 \\
\% \text { PP lebih } \\
\text { dari } 3 \text { periode } \\
\text { pembayaran }\end{array}$ \\
\hline $\begin{array}{c}\text { Murabahah } \\
\text {, Istihna, } \\
\text { Qardh, } \\
\text { Multijasa }\end{array}$ & $\begin{array}{c}\text { Pembayaran } \\
\text { angsuran } \\
\text { tepat waktu } \\
\text { dan tidak ada } \\
\text { tunggakan } \\
\text { serta sesuai } \\
\text { dengan } \\
\text { persyaratan } \\
\text { akad }\end{array}$ & $\begin{array}{c}\text { Terdapat } \\
\text { tunggakan } \\
\text { pembayaran } \\
\text { angsuran } \\
\text { pokok dan } \\
\text { atau margin } \\
\text { s/d } 90 \text { hari }\end{array}$ & $\begin{array}{c}\text { Terdapat } \\
\text { tunggakan } \\
\text { pembayaran } \\
\text { angsuran } \\
\text { pokok dan atau } \\
\text { margin yang } \\
\text { telah melewati } \\
90 \text { hari s/d } 180 \\
\text { hari }\end{array}$ & $\begin{array}{c}\text { Terdapat } \\
\text { tunggakan } \\
\text { pembayaran } \\
\text { angsuran } \\
\text { pokok dan } \\
\text { atau margin } \\
\text { yang telah } \\
\text { melewati } 180 \\
\text { hari s/d } 270 \\
\text { hari }\end{array}$ & $\begin{array}{c}\text { Terdapat } \\
\text { tunggakan } \\
\text { pembayaran } \\
\text { angsuran } \\
\text { pokok dan } \\
\text { atau margin } \\
\text { yang telah } \\
\text { melewati } 270 \\
\text { hari. }\end{array}$ \\
\hline IJARAH & $\begin{array}{c}\text { Pembayaran } \\
\text { sewa tepat } \\
\text { waktu }\end{array}$ & $\begin{array}{c}\text { Terdapat } \\
\text { tunggakan } \\
\text { sewa s/d } 90 \\
\text { hari }\end{array}$ & $\begin{array}{c}\text { Terdapat } \\
\text { tunggakan } \\
\text { sewa yang } \\
\text { telah melewati } \\
90 \text { hari s/d } 180 \\
\text { hari }\end{array}$ & $\begin{array}{c}\text { Terdapat } \\
\text { tunggakan } \\
\text { sewa yang } \\
\text { telah } \\
\text { melewati } 180 \\
\text { hari s/d } 270 \\
\text { hari }\end{array}$ & $\begin{array}{l}\text { Terdapat } \\
\text { tunggakan } \\
\text { sewa yang } \\
\text { telah } \\
\text { melampaui } \\
270 \text { hari }\end{array}$ \\
\hline SALAM & $\begin{array}{c}\text { Piutang salam } \\
\text { belum jatuh } \\
\text { tempo }\end{array}$ & $\begin{array}{c}\text { Piutang salam } \\
\text { telah jatuh } \\
\text { Itempo s/d } 90 \\
\text { hari }\end{array}$ & $\begin{array}{l}\text { Piutang salam } \\
\text { telah jatuh } \\
\text { tempo s/d } 60 \\
\text { hari }\end{array}$ & $\begin{array}{c}\text { Piutang Salam } \\
\text { telah jatuh } \\
\text { tempo s/d } 90 \\
\text { hari }\end{array}$ & $\begin{array}{c}\text { Piutang Salam } \\
\text { telah jatuh } \\
\text { tempo } \\
\text { melebihi } 90 \\
\text { hari }\end{array}$ \\
\hline
\end{tabular}




\section{J-HES}

Jurnal Hukum Ekonomi Syariah

Volume 2, No. 1, Januari-Juni 2018 | p-ISSN: 2549-4872 | e-ISSN: 2654-4970

\section{Sebab-Sebab Pembiyaan}

\section{Bermasalah}

Berdasarkan Pasal 23 dan Penjelasan Pasal 37 ayat (1) UU No. 21 Tahun 2008 tentang Perbankan Syariah, dapat disimpulkan bahwa Penyaluran dana oleh Bank Syariah mengandung risiko kegagalan atau kemacetan dalam pelunasannya, sehingga dalam pelaksanaannya bank harus benar-benar memperhatikan asas-asas penyaluran dana/pembiayaan yang sehat.

Apabila bank

tidak

memperhatikan asas-asas pembiayan yang sehat dalam menyalurkan pembiayaannya, maka akan timbul berbagai risiko yang harus ditanggung oleh bank antara lain berupa:

a. Hutang/ kewajiban pokok pembiayaan tidak dibayar;

b. Margin / Bagi hasil / fee tidak dibayar;

c. Membengkaknya biaya yang dikeluarkan;

d. Turunnya kesehatan pembiayaan (finance soundness).

Risiko-risiko tersebut dapat mengakibatkan timbulnya pembiayaan bermasalah (non performing financings/NPFs), yang pada akhirnya dapat menurunkan tingkat kesehatan bank dan juga akan berpengaruh pula kepada keamanan dana masyarakat yang ada di bank tersebut. Oleh karenanya, memahami sebab-sebab timbulnya pembiayaan bermasalah menjadi hal yang penting.

Secara umum pembiayaan bermasalah dapat terjadi karena disebabkan oleh faktor-faktor intern dan faktor-faktor ektern. Faktor Intern adalah faktor yang ada di dalam perusahaan sendiri, dan faktor utama yang paling dominan adalah faktor manajerial. Misalnya kelemahan dalam kebijakan pembelian dan penjualan, lemahnya pengawasan biaya dan pengeluaran, kebijakan piutang yang kurang tepat, penempatan yang berlebihan pada aktiva tetap, dan permodalan yang tidak cukup. Faktor Ektern adalah faktor-faktor yang berada di luar kekuasaan manajemen perusahaan, seperti bencana alam, peperangan, perubahan dalam kondisi perekonomian dan perdagangan, perubahan-perubahan teknologi, dan lain-lain. ( Zainul Arifin, 2002, 244)

Untuk menentukan langkah yang perlu diambil dalam menghadapi pembiayaan bermasalah terlebih dahulu perlu diteliti sebab-sebab terjadinya pembiayaan bermasalah. 
Bila pembiayaan bermasalah disebabkan oleh faktor eksternal seperti bencana alam, bank tidak perlu lagi melakukan analisis lebih lanjut. Yang perlu adalah bagaimana membantu nasabah untuk segera memperoleh penggantian dari perusahaan asuransi. Yang perlu diteliti adalah faktor internal, yaitu yang terjadi karena sebab-sebab manajerial. Bila bank telah melakukan pengawasan secara seksama dari bulan ke bulan, dari tahun ke tahun, lalu timbul pembiayaan bermasalah, sedikit banyak terkait pula dengan kelemahan pengawasan itu sendiri. Kecuali apabila aktivitas pengawasan telah dilaksanakan dengan baik, masih juga terjadi kesulitan keuangan, perlu diteliti sebab-sebab pembiayaan bermasalah secara lebih mendalam. Mungkin kesulitan itu disengaja oleh manajemen perusahaan, yang berarti pengusaha telah melakukan hal-hal yang tidak jujur.

\section{Upaya-upaya untuk Mengantisipasi Risiko Pembiayaan Bermasalah/Macet}

Secara penanggulangan garis pembiayaan

bermasalah dapat dilakukan melalui upaya-upaya yang bersifat preventif dan upaya-upaya yang bersifat represif / kuratif.

Upaya-upaya yang bersifat preventif (pencegahan) dilakukan oleh bank sejak permohonan pembiayaan diajukan nasabah, pelaksanaan analisa yang akurat terhadap data pembiayaan, pembuatan perjanjian pembiayaan yang benar, pengikatan agunan yang menjamin kepentingan bank, sampai dengan pemantauan atau pengawasan terhadap pembiayaan yang diberikan.

Sedangkan upaya-upaya yang bersifat represif / kuratif adalah upayaupaya penanggulangan yang bersifat penyelamatan atau penyelesaian terhadap pembiayaan bermasalah (non performing financings/NPFs).

\section{Penyelamatan Pembiayaan Bermasalah}

Penyelamatan pembiayaan adalah istilah teknis yang biasa dipergunakan dikalangan perbankan terhadap upaya dan langkah-langkah yang dilakukan bank dalam usaha mengatasi permasalahan pembiayaan yang dihadapi oleh debitur yang masih memiliki prospek usaha yang baik. Namun mengalami kesulitan pembayaran pokok dan/atau kewajiban- 


\section{J-HES}

Jurnal Hukum Ekonomi Syariah

Volume 2, No. 1, Januari-Juni 2018 | p-ISSN: 2549-4872 | e-ISSN: 2654-4970

kewajiban lainnya, agar debitur dapat memenuhi kembali kewajibannya.

Dalam peraturan perundangundangan yang berlaku bagi bank yang melaksanakan kegiatan berdasarkan prinsip syariah, terdapat beberapa ketentuan Bank Indonesia yang memberikan pengertian tentang restrukturisasi pembiayaan, yaitu:

$\begin{array}{llr}\text { a. Peraturan Bank Indonesia } \\ \text { No.10/18/PBI/2008 } & \text { tentang }\end{array}$

Restrukturisasi Pembiayaan bagi

Bank Syariah dan Unit Usaha Syariah, sbb:

Restrukturisasi Pembiayaan adalah upaya yang dilakukan oleh Bank dalam rangka membantu nasabah agar dapat menyelesaikan kewajibannya, antara lain melalui:

1) Penjadwalan kembali (rescheduling), $\quad$ yaitu perubahan jadwal pembayaran kewajiban nasabah atau jangka waktunya;

2) Persyaratan kembali (reconditioning), yaitu perubahan sebagian atau seluruh persyaratan Pembiayaan, antara lain perubahan jadwal pembayaran, jumlah angsuran, jangka waktu dan/atau pemberian potongan sepanjang tidak menambah sisa kewajiban nasabah yang harus dibayarkan kepada Bank;

b. Penataan kembali (restructuring), yaitu perubahan persyaratan Pembiayaan tidak terbatas pada rescheduling atau reconditioning.

c. Peraturan Bank Indonesia No.8/12/PBI/2006 tanggal 10 Juli 2006 tentang Laporan Berkala Bank Umum, Penjelasan Pasal 2 ayat (4) huruf $g$ :

"Restrukturisasi Pembiayaan adalah upaya perbaikan yang dilakukan bank dalam kegiatan pembiayaan, piutang, dan atau ijarah terhadap debitur yang mengalami kesulitan untuk memenuhi kewajibannya."

d. PBI No 8/21/PBI/2006 tgl 5 Oktober 2006 tentang Penilaian Kualitas Aktiva Bank Umum Yang Melaksanakan Kegiatan Usaha Berdasarkan Prinsip Syariah, Pasal 1 butir 31:

"Restrukturisasi Pembiayaan
adalah upaya perbaikan yang
dilakukan Bank dalam kegiatan
Penyediaan Dana terhadap
nasabah yang mengalami
kesulitan untuk memenuhi
kewajibannyadengan mengikuti
ketentuan yang berlaku yaitu
fatwa Dewan Syariah Nasional
dan Standar Akuntansi


Keuangan yang berlaku bagi bank syariah."

Dari berbagai ketentuan Bank Indonesia di atas dapat disimpulkan bahwa berdasarkan tujuannya, penyelamatan pembiayaan merupakan upaya dan langkah-langkah restrukturisasi yang dilakukan bank dengan mengikuti ketentuan yang berlaku agar pembiayaan non lancar (golongan kurang lancar, diragukan dan macet) dapat menjadi atau secara bertahap menjadi golongan lancar kembali.

\section{Bentuk-bentuk Restrukturisasi \\ Dalam Rangka Penyelamatan} Pembiayaan Bermasalah, dari ketentuan-ketentuan Bank Indonesia pada uraian di atas, restrukturisasi pembiayaan berdasarkan prinsip syariah meliputi :

a) penurunan imbalan atau bagi hasil;

b) pengurangan tunggakan imbalan atau bagi hasil;

c) pengurangan tunggakan pokok pembiayaan;

d) perpanjangan jangka waktu pembiayaan;

e) penambahan fasilitas pembiayaan;

f) pengambialihan aset debitur sesuai dengan ketentuan yang berlaku;

g) konversi pembiayaan menjadi penyertaan pada perusahaan debitur.
Di samping itu, sebagai contoh, berdasarkan Penjelasan Pasal 46 ayat (3) PBI No 8/21/PBI/2006, upaya dan mekanisme restrukturisasi pembiayaan dilakukan sesuai dengan ketentuan yang berlaku yang antara lain untuk Murabahah bisa dilakukan dengan memberi potongan dari total kewajiban pembayaran, penjadwalan kembali, dan konversi akad murabahah yang dilaksanakan sesuai dengan fatwa Dewan Syariah Nasional yang berlaku.

Khusus mengenai konversi akad Murabahah, Fatwa DSN No. 49/DSNMUI/11/2005 antara lain menyatakan bahwa Lembaga Keuangan Syariah boleh melakukan konversi akad murabahah bagi nasabah yang tidak dapat menyelesaikan/ melunasi pembiayaan murabahahnya sesuai jumlah dan waktu yang telah disepakati, tetapi ia masih prospektif, dengan ketentuan sebagai berikut:

a. Akad murabahah dihentikan dengan cara:

1) Obyek murabahah dijual oleh nasabah kepada LKS dengan harga pasar;

2) Nasabah melunasi sisa hutangnya kepada LKS dari hasil penjualan; 


\section{J-HES}

Jurnal Hukum Ekonomi Syariah

Volume 2, No. 1, Januari-Juni 2018 | p-ISSN: 2549-4872 | e-ISSN: 2654-4970

3) Apabila hasil penjualan melebihi sisa hutang maka kelebihan itu dapat dijadikan uang muka untuk akad ijarah atau bagian modal dari mudharabah dan musyarakah;

4) Apabila hasil penjualan lebih kecil dari sisa hutang maka sisa hutang tetap menjadi hutang nasabah yang cara pelunasannya disepakati antara LKS dan nasabah.

b. LKS dan nasabah eks-murabahah tersebut dapat membuat akad baru dengan akad:

1) Ijarah Muntahiyah Bit Tamlik (IMBT) atas barang tersebut;

2) Mudharabah, atau

3) Musyarakah.

Apabila disandingkan PBI No. 8/21/PBI/2006 dengan Fatwa DSNMUI No. 49/DSN-MUI/11/2005 di atas, maka dapat disimpulkan bahwa konversi akad murabahah kepada akad pembiayaan mudharabah atau musyarakah atau IMBT sebagaimana disebutkan dalam fatwa, merupakan bagian dari restrukturisasi pembiayaan sebagaimana diatur dalam PBI No. 8/21/PBI/2006.

\section{Peyelesaian Pembiayaan Macet}

Penyelesaian Pembiayaan Macet (atau ketegori Golongan V) adalah upaya dan tindakan untuk menarik kembali pembiayaan nasabah/debitur dengan kategori macet, terutama yang sudah jatuh tempo atau sudah memenuhi syarat pelunasan.

Secara garis besar, usaha penyelesaian pembiayaan macet dapat dibedakan berdasarkan kondisi hubungannya dengan nasabah debitur, apakah ia bersikap kooperatif atau tidak. Apabila dalam penyelesaian pembiayaan tersebut pihak debitur masih kooperatif, sehingga usaha penyelesaian dilakukan secara kerjasama antara debitur dan bank, dalam hal ini disebut sebagai "penyelesaian secara damai" atau “penyelesaian secara persuasif”. Namun apabila dalam penyelesaian pembiayaan tersebut pihak debitur tidak kooperatif lagi, sehingga usaha penyelesaian dilakukan secara pemaksaan dengan melandaskan pada hak-hak yang dimiliki oleh bank, dalam hal ini penyelesaian tersebut disebut "penyelesaian secara paksa".

Sumber-sumber penyelesaian pembiayaan antara lain berupa: 
a. Barang-barang yang dijaminkan kepada bank. Dalam fikih didasarkan kepada prinsip rahn.

b. Jaminan perorangan (borgtocht), baik dari orang perorangan maupun dari badan hukum. Dalam fikih didasarkan kepada prinsip kafalah.

c. Seluruh harta kekayaan debitur dan pemberi jaminan (lihat pasal 1131 KUH Perdata), termasuk yang dalam bentuk piutang kepada bank sendiri (kalau ada). Dalam fikih, hal ini antara lain didasarkan kepada Hadis Rasulullah Saw, sbb: Dari Ka`ab bin Malik, "Sesungguhnya Nabi SAW pernah menyita harta milik Muaddz lalu beliau menjualnya untuk membayar utangnya " (HR. Imam Daruquthni).

d. Pembayaran dari pihak ketiga yang bersedia melunasi hutang debitur. Dalam fikih didasarkan kepada prinsip hawalah atau kafalah.

Dengan dasar dan prinsipprinsip tersebut, strategi penyelesaian pembiayaan macet yang dapat ditempuh oleh Bank adalah berupa tindakantindakan sebagai berikut: a. Penyelesaian oleh bank sendiri

b. Penyelesaian melalui debt collector

c. Penyelesaian melalui Kantor Lelang

d. Penyelesaian melalui badan peradilan (al-qadha)

e. Penyelesaian melalui badan arbitrase (Tahkim)

f. Penyelesaian melalui Direktorat Jenderal Piutang dan Lelang Negara (DJPLN)

g. Penyelesaian Melalui Kejaksaan Bagi Bank-bank BUMN

h. Kebijakan Hapus Buku dan Hapus Tagih

\section{KESIMPULAN}

Adanya pembiayaan bermasalah pada bank syariah secara langsung atau tidak langsung dapat memberikan dampak risiko bagi bank itu sendiri maupun secara nasional. Dilihat dari segi produktivitasnya (performancenya) yaitu dalam kaitannya dengan kemampuannya menghasilkan pendapatan bagi bank, adanya pembiayaan bermasalah akan berakibat pada berkurang atau menurunnya pendapatan bank dan bahkan mungkin sudah tidak ada lagi. Risiko lainnya adalah adanya kewajiban bagi bank untuk memperbesar biaya pencadangan, yaitu pencadangan Penyisihan Penghapusan Aktiva Produktif (PPAP). 


\section{J-HES}

Jurnal Hukum Ekonomi Syariah

Volume 2, No. 1, Januari-Juni 2018 | p-ISSN: 2549-4872 | e-ISSN: 2654-4970

Adanya PPAP yang besar, maka akan mengurangi produktifitas dana yang dikelola oleh bank tersebut. Sedangkan dari segi nasional, hal tersebut akan mengurangi kontribusi bank dalam melakukan fungsi intermediarinya sehingganya tidak dapat memberikan kontribusi pada pembangunan dan pertumbuhan ekonomi.

Penanggulangan pembiayaan bermasalah dapat dilakukan melalui upaya-upaya yang bersifat preventif dan upaya-upaya yang bersifat represif/kuratif. Upaya-upaya yang bersifat preventif (pencegahan) dilakukan oleh bank sejak permohonan pembiayaan diajukan nasabah sampai dengan pemantauan atau pengawasan terhadap pembiayaan yang diberikan. Sedangkan upaya-upaya yang bersifat represif/kuratif adalah upaya-upaya penanggulangan yang bersifat penyelamatan atau penyelesaian terhadap pembiayaan bermasalah (non performing financings/NPFs).

Secara garis besar, usaha penyelesaian pembiayaan macet dapat dilakukan melalui penyelesaian oleh bank sendiri secara bertahap dengan pendekatan persuasif. Bila tahap pertama tersebut telah dilakukan, maka dapat digunakan langkah dan tahapan berikutnya antara lain penyelesaian melalui debt collector, penyelesaian melalui Kantor Lelang, penyelesaian melalui badan peradilan (al-qadha), penyelesaian melalui badan arbitrase (tahkim) dan Penyelesaian melalui Direktorat Jenderal Piutang dan Lelang Negara (DJPLN) untuk bank-bank BUMN.

\section{DAFTAR PUSTAKA}

Arifin, Zainul. Dasar-Dasar Manajemen Bank Syariah. Jakarta: Alvabet, 2002.

Chapra, Umer and Tariqullah Khan. Regulation and Supervision of Islamic Banks. Jeddah: IRTI- IDB, 2000.

Darus, Mariam. Aneka Hukum Bisnis. Bandung: Citra Aditya Bakti, 1997.

Djamil, Fathurrahman. Penyelesaian Pembiayaan Bermasalah di Bank Syariah. Jakarta: Sinar Grafika, 2012.

Fatullah Said, Abdullah as-Sattar. al-Muamalah fi al-Islam. Mekkah: Rabithah al'Alam al-Islami, 1402H.

Imtiyazuddin Ahmad (ed.). Islamic Banking and Finance The Concept, The Practice and The Challenge. Plainfield: The Islamic Society of North Amerika 1999.

Penanganan Pembiyaan Bermasalah pada Bank Syariah | 108 
Kumpulan Fatwa Dewan Syariah Nasional

Peraturan Bank Indonesia No. 8/21/PBI/2006 tentang Kualitas Aktiva Bank Umum yang Melaksanakan Kegiatan Usaha Berdasarkan Prinsip Syariah sebagaimana diubah dengan PBI No. 9/9/PBI/2007 dan PBI No. 10/24/PBI/2008.

Peraturan Bank Indonesia No.10/18/PBI/2008 tentang Restrukturisasi Pembiayaan bagi Bank Syariah dan Unit Usaha Syariah.

Peraturan Bank Indonesia No.8/12/PBI/2006 tanggal 10 Juli 2006 tentang Laporan Berkala Bank Umum

Saeed, Abdullah. Islamic Banking and Interest : A Study of Prohibition of Riba and Its Contemporary Interpretations. Leiden : EJ. Brill, 1996.

Siamat, Dahlan. Lembaga Manajemen Keuangan. Edisi III, FE-UI, Jakarta, 2001.

Siddiqie,Moh. Nejatullah. Issues In Syariah Banking. Leicester: Syariahic Foundation, 1985.

Sjahdeini, Sutan Remy. Kebebasan Berkontrak dan Perlindungan yang Seimbang bagi Para pihak dalam Perjanjian Kredit Bank di Indonesia. Jakarta: Inatitut Bankir Indonesia, 1993.

Sjahdeini, Sutan Remy. Kredit Sindikasi Proses Pembentukan dan Aspek Hukum. Jakarta: Grafiti, 1997.

Statistik Bank Syariah Bulan Mei 2010. www.bi.go.id.

Subekti. Aneka Perjanjian. Cet. Ke-10; Bandung: Citra Aditya Bakti, 1995.

Supyadillah, Asep. Hukum Perbankan Syariah. Jakarta: Wahana Kardofa, 2013.

Surat Edaran Bank Indonesia No. 8/22/DPbS tanggal 18 Oktober 2006 tentang Penilaian Aktiva Produktiv Bank Umum Yang Melaksanakan Kegiatan Usaha Berdasarkan Prinsip Syariah sebagaimana diubah dengan SEBI No. 10/36/DPbS tanggal 22 Oktober 2008.

Undang-undang No. 30 tahun 1999 tentang Arbitrase dan Alternatif Penyelesaian Sengketa

Undang-undang No. 37 tahun 2004 tentang Kepailitan dan Penundaan Kewajiban Pembayaran Utang

Undang-undang No. 4 Tahun 1996 tentang Hak Tanggungan

Undang-undang No. 42 tahun 1999 tentang Jaminan Fidusia

Undang-Undang No. 49 Prp Tahun 1960 tentang Pengurusan Piutang Negara

Undang-undang No. 7 Tahun 1989 tentang Peradilan Agama sebagaimana diubah dengan UU No. 3 Tahun 2006 dan UU No. 50 Tahun 2009.

Undang-Undang No. tahun 1992 tentang Perbankan sebagaimana diubah dengan UU No. 10 Tahun 1998.

Undang-Undang No.21 Tahun 2008 tentang Perbankan Syariah 